\title{
The current composition of the family Gobiidae Cuvier, 1816 (Actinopterygii) in waters of Ukraine with comments on species distributions
}

\section{Leonid Manilo}

National Museum of Natural History, NAS of Ukraine (Kyiv, Ukraine)

\begin{abstract}
The current composition of the family Gobiidae Cuvier, 1816 (Actinopterygii) in waters of Ukraine with comments on species distributions. - L. Manilo. - The present paper is devoted to a literature-based retrospective analysis of changes in the species composition of the family Gobiidae of waters of Ukraine since the 1930s. Keys and checklists published earlier cover the fish fauna of separate regions of Ukraine, either only of river basins or of coastal waters of the Black Sea and the Sea of Azov. The first checklist of fishes of Ukraine was published by academician A. M. Nikolsky in 1930 including both freshwater and marine species known in that time. In that work, the family Gobiidae includes 23 species of 7 genera. In the paper by D. A. Tretyakov (1947), 23 species of 10 genera of true gobies are listed for waters of Ukraine with some changes in the species composition. In one of the volumes of the series "Fauna of Ukraine. Fishes" devoted to true gobies (Smirnov 1986), data on 25 species of 11 genera are presented. According to the data by Yu. Movchan (2011), the composition of the family largely expanded comprising 33 species of 13 genera, including 5 marine species that were recorded in that time in coastal waters of the Crimea as well as 1 newly described species from the Chorna River. Later, five more marine species, known earlier only in the Mediterranean Basin, were found in waters of Ukraine, as well as another species in the Sea of Azov. It was established that the current fish fauna of the family Gobiidae of Ukraine includes 38 species of 17 genera, according to the literature and data from the fish collection of the National Museum of Natural History NAS of Ukraine (Kyiv). The geographic range and distribution of each species in waters of Ukraine are presented. The fauna of true gobies of Ukraine is composed of species of the Ponto-Caspian (52.6\%) and Atlantic-Mediterranean (47.4\%) faunal complexes. Endemics (4 species) are highlighted along with recent intruders of the Black Sea that have appeared here since the early 2000s ( 8 species); the time of appearance for 2 species remains unknown.
\end{abstract}

Key words: Gobiidae, genus, species, distribution, Ukraine, Black Sea, Sea of Azov, faunal complex, endemic species.

\section{Introduction}

True gobies (Gobiidae) are one of the largest family of the order Gobiiformes that includes 1359 species of 189 genera (Nelson et al. 2016) distributed in tropical and temperate latitudes from the intertidal zone to a depth of $200 \mathrm{~m}$. True gobies are important components of fish diversity having a significant role in trophic chains of water ecosystems. In the fish fauna of Ukraine, the family of true gobies is the second largest by the number of species after the cyprinids (Cyprinidae).

Many of the earlier published checklists and keys to fishes cover mainly the whole fish fauna of separate regions (Ostroumov 1896; Sushkin \& Beling 1923; etc.), while others deal only with freshwater fish faunas (Markevych \& Korotkyy 1954), species composition of fishes of separate river basins, regions, or coastal waters of Ukraine (Vladykov 1926; Kolyushev 1949; Lyashenko 1952; Manilo 2014; etc.). Therefore, these publications cannot present the entire family of true gobies.

One of the first publications with a description of the fish fauna of Ukraine was the work by academician A. M. Nikolsky (1930), in which the author considers not only freshwater, but also marine species of coastal waters of Ukraine in the Black Sea and the Sea of Azov. In this key, the family Gobiidae is represented by 23 species of 7 genera, such as Gobiosoma, Aphia, Pomatoschistus, Gobius, Proterorhinus, Benthophilus and Benthophiloides.

The systematics of true gobies started to develop intensely after the studies of the lateral line system in different genera and species by B. S. Ilin $(1927,1949)$. In the "Key to Cyclostomes and Fishes of

Correspondence to: Leonid Manilo; National Museum of Natural History, NAS of Ukraine; Bohdan Khmelnytsky St. 15, Kyiv, 01030 Ukraine; e-mail: leonid.manilo@gmail.com; orcid: 0000-0002-7143-9470 
the Ukrainian SSR" by D. K. Tretyakov (1947), 23 species of 10 genera of true gobies are presented for waters of Ukraine (three genera are added: Knipowitschia, Zostericola, Bubyr along with modifications in the species composition), and gobies are first considered among other local literature sources as a separate order Gobiiformes.

In the following years, many papers and monographs were published devoted to different aspects of systematics, biology, and distribution of gobies. In 1980-1988, the series "Fauna of Ukraine. Fishes" was published (issues 1-5 in six books), including an issue dedicated to gobies (Smirnov 1986). In that publication, the author considers 25 species of 11 genera in the composition of the family Gobiidae.

Yu. V. Movchan (2011), based on a survey and analysis of novel ichthyological data, generalised the materials of numerous sources on fishes of waters of Ukraine, including gobies. According to this publication, the composition of Gobiidae significantly expanded up to 33 species of 12 genera, including marine species (Pomatoschistus bathi, Millerigobius macrocephalus, Gobius cruentatus, and G. xanthocephalus) that were discovered in coastal waters of the Crimea by scientists of the Institute of Biology of Southern Seas, NAS of Ukraine (Boltachev et al. 2009a, 2010; Boltachev \& Karpova 2010). Additionally, a new species Proterorhinus tataricus was described from the Chorna River (Freyhof \& Naseka 2007).

Later, several other species were discovered in coastal waters of the Crimea previously known to be occurring only in the Mediterranean Basin: Chromogobius quadrivittatus (Kovtun 2013), Gammogobius steinitzi (Kovtun \& Manilo 2013), as well as Benthophilus magistri from the Sea of Azov (Manilo 2011a). These species were included into L. G. Manilo's monograph, and the number of species and genera increased to 34 and 17, respectively (Manilo 2014).

Afterwards, a number of Mediterranean species were discovered in coves of Sevastopol and underwater caves of Cape Tarkhankut: Chromogobius zebratus, Gobius couchi, and Zebrus zebrus (Kovtun \& Karpova 2014; Karpova \& Boltachev 2018).

However, there are no publications dealing with the complete current composition of the family of waters of Ukraine, including both freshwater and marine species. Therefore, the aim of the present paper is to generalise knowledge and to determine the current composition of the family Gobiidae along with the distribution of species.

\section{Material and Methods}

The study is based on results of a retrospective analysis of literature on the composition and distribution of fishes of the family Gobiidae occurring in waters of Ukraine. The systematics and nomenclature of true gobies are presented based on their validity according to modern ichthyological research (Froese \& Pauly 2019).

Based on recent data of phylogenetic and biogeographic analyses (Neilson \& Stepien 2009), the expansion of the taxonomic volume of subfamily Benthophilinae (based on the tribe Benthophilini Beling et Iljin, 1927) by inclusion of the genus Neogobius and other close genera is substantiated. This subfamily is divided into three tribes: Benthophilini, Neogobiini, and Ponticolini. The tribe Ponticolini, in addition to the genera Mesogobius and Proterorhinus, also includes Babka and Ponticola as independent genera. Thus, the system of the family of true gobies is presented in this paper according to these data.

The unit of zoogegographic analysis is a faunal complex, i.e. a group a species connected by common geographic origin (Nikolsky 1947). Due to the complex geological past of the Azov-Black Sea Basin, its fish fauna, including the family Gobiidae, has a multifarious origin and includes representatives of different faunal complexes such as Boreal-Atlantic, Mediterranean, and Ponto-Caspian (Zenkevich 1963). According to more recent views (Zaitsev 1998), the ichthyofauna of the Black Sea was ultimately formed after the last connection between the Black Sea and the Mediterranean Sea. Species of the Boreal-Atlantic complex had already been present in the compostion of the Mediterranean complex before the Dardanelles appeared, thus this complex is considered in this paper as Atlantic-Mediterranean. 
All species of the Ponto-Caspian complex are Ponto-Caspian endemics by their origin. In this paper, endemics are considered based on their current distribution, i.e. a species is considered endemic if its distribution is restricted to the Black Sea and Sea of Azov or has an even narrover range (e.g. Pr. tataricus).

Among the representatives of the Atlantic-Mediterranean complex, recent invaders that appeared in the Azov-Black Sea Basin in the last few decades are highlighted.

\section{Systematic Part}

\section{Order Gobiiformes}

\section{Family Gobiidae}

\section{Subfamily Benthophilinae}

\section{Tribe Benthophilini Neilson et Stepien, 2009}

\section{Genus Benthophiloides Beling et Iljin, 1927}

The genus includes two species distributed in estuaries and rivers of the Black and Caspian Seas. One species occurs in waters of Ukraine.

\section{Benthophiloides brauneri Beling et Iljin, 1927}

A species of the Ponto-Caspian faunal complex. The only representative of the genus in the fauna of Ukraine. Inhabits estuaries, bays, river mouths, reservoirs, and coastal waters of the northwest part of the Black Sea and the Sea of Azov. In Ukraine, it was recorded in the middle and upper sections of the Dnipro Estuary (Snigirov 2014), in Odesa Bay (Cape Velyky Fontan), in the Bug Estuary from Nova Odesa to Mykolaiv, in the course of the Dnipro from Kherson to Kakhovka, in Tendra Bay, and in the upper sections of the Dnipro (Novitsky et al. 2008; Stepanok \& Hubanov 2018; Tkachenko 2018) and Kaniv Reservoirs (Manilo et al. 2013b). One record of the species is also known from Tatar cove of Kazantip Bay, Sea of Azov (Boltachev et al. 2009b).

\section{Genus Benthophilus Eichwald, 1831}

According to data from different sources, the genus includes 18-20 species (Boldyrev \& Bogutskaya 2007), most of which inhabit the Caspian Sea. In waters of Ukraine, three species occur (Manilo 2011). Some researchers (Shandikov \& Goncharov 2008) suggest the presence of another species Benthophilus durrelli Boldyrev et Bogutskaya, 2004 in the Siversky Donets River.

Benthophilus magistri Iljin, 1927

A species of the Ponto-Caspian faunal complex. Endemic to the Sea of Azov, where inhabits its eastern part from Taganrog Bay (Mius and Yeya Estuaries) to Temryuk Bay (Akhtanizovskiy Estuary). The species is absent in the western part of the Sea of Azov and in Lake Syvash. Occurs in Taganrog Bay from its mouth between Bilosaraiska and Dovha Spits to the mouth of the Don River. In waters of Ukraine, the species is recorded in the middle section of Taganrog Bay near Kryva Spit (Manilo $2011 a, 2014)$.

\section{Benthophilus nudus Berg, 1898}

A species of the Ponto-Caspian faunal complex. Distributed in the northwest part of the Black Sea and in adjacent estuaries, lakes, and rivers. In waters of Ukraine, the species occurs near Zmiinyi Island, in the mouth of the Danube River and adjacent lakes, in the Sasyk Estuary (Demchenko \& Smirnov 2009), in coastal waters of the Danube-Dnister interfluve, in the Budatsky, Dnister, Tiligul (until 1990) (Shekk 2004), Berezansky, and Dnipro-Bug Estuaries, in the lower section of the Dnister River to Bendery city (Berg 1949), in the Southern Bug River to Oleksandrivka, in the Dnipro River (including its tributaries Samara (Novitsky et al. 2006) and Ingulets (Ambroz 1956)), in Kaniv Reservoir (Goroshko et al. 1989), in the mouth of the Desna River and near Kyiv (Pinchuk et al. 1985), as well as in Tendra Bay. 
Benthophilus stellatus (Sauvage, 1874)

A species of the Ponto-Caspian faunal complex. Endemic to the Sea of Azov. According to literature data, the distribution range of the species covers the Sea of Azov to the Kerch Peninsula, also including Lake Syvash (Boldyrev \& Bogutskaya 2007). According to some researchers, as a result of accidental introduction the species appeared in the Volga River's basin where it dispersed through several waterbodies and now occurs in reservoirs of the Don and Volga Rivers (Vasileva 2007). In waters of Ukraine, the species occurs in the south-western part of the Sea of Azov to Cape Kazantip, as well as along the northern coast from the Utlyuk Estuary to Kryva Spit, including the Molochnyi Estuary (Demchenko et al. 2005; Diripasko et al. 2011).

\section{Genus Caspiosoma Iljin, 1927}

A monotypic genus.

Caspiosoma caspium (Kessler, 1877)

A species of the Ponto-Caspian faunal complex. Its geographic range covers the basins of the Black Sea, Caspian Sea, and the Sea of Azov (Svetovidov 1964; Luzhnyak \& Korneev 2006). In waters of Ukraine, the species occurs in estuaries of the northwest part of the Black Sea, particularly in the Sasyk (Moshu 2006), Berezansky, Dnipro-Bug, and Dnister Estuaries (Strautman \& Pinchuk 1972), as well as from the Dnipro Delta to Kakhovka and in the Southern Bug near Mykolaiv. Not recorded in waterbodies of Ukraine in the last few years.

\section{Tribe Neogobiini Neilson et Stepien, 2009}

\section{Genus Neogobius Iljin, 1927}

The genus comprises four species that inhabit the basins of the Black Sea, Sea of Azov, and the Caspian Sea. Two species occur in waters of Ukraine.

Neogobius fluviatilis (Pallas, 1814)

A species of the Ponto-Caspian faunal complex. Widely distributed in the basin of the Black Sea (in the Danube to Austria (Ahnelt et al. 1998; Jurajda et al. 2005; Szalóky et al. 2015), in the Dnister to its upper course, in the Southern Bug and Dnipro and their tributaries) and of the Sea of Azov (rivers of the Azov Region and the Don with its tributaries). Records of the species are also known from the Aegean (Zogaris \& Apostolou 2011) and Marmara Seas (Sari et al. 2006). Through the system of channels, the species penetrated the basin of the Baltic Sea (Danilkiewicz 1998; Rakauskas et al. 2018) and within the net of European freshwaters reached the Netherlands (Van Kessel et al. 2009). In waters of Ukraine, the species occurs in coastal waters from the Danube Delta in the west to Kryva Spit, Sea of Azov in the east, except for Zmiinyi Island and saline lakes Shagany, Alibei, and Burnas (Manilo 2011b). Occurs practically in all rivers of Ukraine, including their middle and upper courses (Smirnov 1986).

\section{Neogobius melanostomus (Pallas, 1814)}

A species of the Ponto-Caspian faunal complex. Inhabits the basin of the Black Sea, Sea of Azov, and Caspian Sea (Svetovidov 1964), as well as of the Marmara and Aegean Seas (Eryilmaz 2002). In the late 1950s, it was accidently introduced in the Aral Sea and occurred there until the 1980s, but by now disappeared (Bogutskaya et al. 2004). The species got into the basin of the Baltic Sea with ballast waters (Skóra \& Rzeznik 2001). In recent years, it was recorded in the basin of the North Sea (Manné et al. 2013). The species was accidently brought to North America, where it became naturalised and widely distributed in the Great Lakes and rivers that flow into them (Jude 2001; Stepien \& Tumeo 2006; Kornis et al. 2012). In the Black Sea and Sea of Azov, the species occurs along the shores. In Ukraine, it inhabits along the entire coast of the Black Sea and Sea of Azov, in bays and estuaries except for the saline lakes Shagany, Alibei, and Burnas (Manilo 2011b), as well as in deltas of all rivers. The species reaches the middle and upper courses of the Danube, Dnister, Southern Bug, Dnipro, and of rivers of the Azov Basin (Smirnov 1986; Movchan et al. 2003). 
Tribe Ponticolini Neilson et Stepien, 2009

\section{Genus Babka Iljin, 1927}

A monotypic genus.

\section{Babka gymnotrachelus (Kessler, 1857)}

A species of the Ponto-Caspian faunal complex. Inhabits desalinated estuaries, bays, coves, coastal lakes, and rivers of the basin of the Black Sea, Sea of Azov, Caspian Sea, and Sea of Marmara. It penetrated the basin of the Baltic Sea from the Dnipro through the system of canals (Danilkiewicz 1996; Kottelat \& Freyhof 2007), although the route of dispersal according to some other sources is unknown (Grabowska 2005; Grabowska \& Grabowski 2005). Through the Rhine-Main-Danube Canal, it dispersed to Germany along the Danube (Roche et al. 2013). In waters of Ukraine, the species was recorded in lakes of the Danube Delta area (Yalpug, Kagul, Katlabug, etc.), in the Sasyk Estuary (Smirnov \& Tkachenko 2007), in the Dnister from its mouth to the upper course and in its tributaries Zbruch, Zhvanchyk, Strypa, Bystrytsia, Murafa, and Strviazh (Movchan et al. 2003; Grabowski et al. 2016). It also occurs in the Southern Bug from its mouth to Ladyzhyn Reservoir, in the Dnipro to Belorus, in the upper section of the Berezansky, Dnipro-Bug (Pinchuk 1977), and Tiligul (in periods of its desalination) estuaries (Shekk 2004), as well as in Yahorlyk, Dzharylhach, and Tendra Bays (Manilo 2009a). In the basin of the Sea of Azov, the species occurs in the desalinated zone of the northern part of the sea and in rivers of the Northern Azov Region (Smirnov 1986). It was also recorded in reservoirs and lakes of eastern Crimea (Karpova 2009).

\section{Genus Mesogobius Bleeker, 1874}

The genus includes three species that inhabit marine, brackish, and freshwaters of the Azov-Black Sea Basin and the Caspian Sea. One species occurs in waters of Ukraine.

\section{Mesogobius batrachocephalus (Pallas, 1814)}

A species of the Ponto-Caspian faunal complex. Its geographic range covers the Azov-Black Sea Basin, the Bosporus, and the Sea of Marmara (Smirnov 1986). In waters of Ukraine, the species occurs along the coasts, including Zmiinyi Island (Snigiryov 2008), Crimea (Boltachev 2003; Shaganov 2009), Kerch Strait (Shaganov \& Milovanov 2005), western and northern parts of the Sea of Azov to Taganrog Bay (Demchenko et al. 2005). It was also recorded in the lower course of the Danube, in the middle course of the Dnister (Romanesku 2012) and the Southern Bug (to Oleksandrivka) and its tributary Mertvovod, as well as in the Dnipro to Kyiv (Kakhovka, Dnipro, Kremenchug, and Kaniv Reservoirs) (Smirnov 1986; Bulakhov et al. 2008) and in the Obitochna and Berda rivers. The species was not found in saline lakes of the Danube-Dnister interfluve (Shagany, Alibei, and Burnas), nor in the Khadzhibey Estuary (Manilo 2009a).

\section{Genus Ponticola Iljin, 1927}

Initially, the genus Ponticola was described as a subgenus of the genus Gobius Iljin, 1927. In modern systematics of the family, it is accepted as a valid genus, which currently includes 14 Ponto-Caspian species that inhabit the basins of the Black Sea, Sea of Azov, and Caspian Sea. In waters of Ukraine, six species occur.

\section{Ponticola cephalargoides (Pinchuk, 1976)}

A species of the Ponto-Caspian faunal complex. Distributed in the western and north-western parts of the Black Sea from the coast of Bulgaria and Romania to Cape Tarkhankut (western population), in waters of the Kerch Peninsula from Cape Opuk in the Black Sea to Cape Kazantip in the Sea of Azov (eastern population) (Pinchuk 1976; Pinchuk et al. 2003; Manilo \& Peskov 2012). In waters of Ukraine, the species also occurs in the southern part of the Dnipro Estuary, along the seashore from Sychavka, Odesa Oblast to the mouths of the Berezansky and Dnipro-Bug Estuaries, in particular on Dnister and Sanzheiska shoalbanks, in Odesa (Zambriborshch et al. 1995) and Karkinit Bay, as well as near Cape Opuk (Shaganov 2009), in the Kerch Strait (Shaganov \& Milovanov 2005), and in the 
southern part of the Sea of Azov to Cape Kazantip. Rarerly occurs in the northern part of the Sea of Azov near Obitochna and Berdiansk Spits (Manilo 2009a, 2011b).

Ponticola eurycephalus (Kessler, 1874)

A species of the Ponto-Caspian faunal complex. Its geographic range covers the north-western part of the Black Sea from the coast of Bulgaria along the coast of the Crimea to the Kerch Strait (Shaganov \& Milovanov 2005; Shaganov 2009; Eremeev et al. 2012), as well as the Sea of Azov from its southern part to Obitochna and Berdiansk Spits, including estuaries of the Kuban region (Demchenko et al. 2005). In waters of Ukraine, the species was recorded in seaside waters of the Danube Delta (Balatskiy \& Voloshkevich 2005), in the Sasyk Estuary (Moshu 2006; Smirnov \& Tkachenko 2007), and along the coast of the Danube-Dnister interfluve (Manilo 2009a). In the southern part of the Dnister Estuary, it was identified as Neogobius cephalarges (Zambriborshch \& Framudu 1990). The species also occurs in coastal waters from the Dnister Estuary to the mouth of the Dnipro-Bug Estuary (Pinchuk 1977; Shekk 2004); in Karkinit Bay it was mentioned as a species of the complex "G. cephalarges + platyrostris" (Pinchuk 1968; Manilo 2009a). According to some researchers, the north-western population of the species is represented by the subspecies N. eurycephalus odessicus Pinchuk, 1977 (Manilo \& Peskov 2012).

\section{Ponticola kessleri (Günther, 1861)}

A species of the Ponto-Caspian faunal complex. Distributed in marine and freswaters of the basin of the Black Sea (Svetovidov 1964; Kottelat \& Freyhof 2007). The species is absent in the basin of the Sea of Azov. In the last years, the species was recorded in the basin of the Rhine to which it entered throught the Main-Danube Canal (Manné et al. 2013; Borcherding et al. 2011). In waters of Ukraine, the species is known from lakes of the Danube Delta area such as Kytay, Katlabug, Yalpug, and Kagul (Smirnov 1986). Also inhabits the Dnister to the mouth of its tributary Bystrytsia (Pinchuk 1977), in the middle and lower courses of the Southern Bug and some of its tributaries (Movchan et al. 2003), as well as in the Dnipro to Kyiv (Smirnov 1986). The species was also recorded in the upper section of the Sasyk (Moshu 2006) and Dnister Estuaries (Movchan et al. 2003), in the lower part of the Khadzhibey Estuary (Kvach et al. 2009), and in the lower course of the Alma River in the Crimea (Boltachev \& Karpova 2017).

\section{Ponticola platyrostris (Pallas, 1814)}

A species of the Ponto-Caspian faunal complex. An endemic of the Black Sea known from the western coast of the Crimea up to Georgia in the east; it was also found off the coast of Turkey near Samsun (Vasileva 2007). Its records in checklists of fishes of coastal waters of Bulgaria (Vassilev \& Pehlivanov 2005) and Romania (Radu \& Radu 2008) belong to other goby species. In waters of Ukraine, the species occurs near Cape Tarkhankut, in the west of the Crimea (Kacha) (Manilo 2009b), as well as along the southern coast of the Crimea from Yalta to Karadag Nature Reserve (Vynogradov 1947) and Feodosia (Shaganov 2009). Rarerly occurs in the southern part of the Kerch Strait, probably only during exchange of saline waters from the Black Sea. The inclusion of the species into the checklist of the ichthyofauna of the lower course of the Dnipro (Movchan 2001) and of the middle course of the Southern Bug (Movchan et al. 2002) is erroneous.

\section{Ponticola ratan (Nordmann, 1840)}

A species of the Ponto-Caspian faunal complex. Its geographic range covers the basins of the Black Sea (from the coast of Bulgaria to the western part of the Crimea and from the Kerch Strait to Novorossiysk), the Sea of Azov (northern and eastern parts), and the Caspian Sea (Vasileva 2007). In waters of Ukraine, the species was recorded near Zmiinyi Island (Snigiryov 2008), from the coast of the Danube-Dnister interfluve to Tendra Bay, including Shagan and Dnister shoalbanks (Manilo 2009a), in the southern part of the Dnister Estuary, in the Khadzhibey, Tiligul (from 1970 to 1990) (Shekk 2004), Berezansky, and Dnirpo-Bug Estuaries, as well as in the Southern Bug to Bilousivka 
(Beling 1927). Pinchuk et al. (1985) mentioned an isolated dwarf population of the species in the lower part of Kakhovka Reservoir near Berislav. In freshwaters, the species was found in Kamyanske (Dniprodzerzhynsk) Reservoir nearby to the mouth of the Dnipro-Donbas Canal (Manilo \& Didenko 2013) and in Kaniv Reservoir (author's unpublished data). The species was also recorded near the Tarkhankut Peninsula (Pinchuk 1968; Eremeev et al. 2012), near Karadag and off the coast of the Kerch Peninsula; it is abundant in the Kerch Strait (Shaganov 2009). The species is also known from the southern part of the Sea of Azov to Cape Kazantip (Eremeev et al. 2012), in the Utlyuk (Demchenko et al. 2005) and Molochnyi (during contact with the sea) Estuaries (Smirnov 2006), as well as in the northern part of the sea to Berdyansk Spit.

Ponticola syrman (Nordmann, 1840)

A species of the Ponto-Caspian faunal complex. Its geographic range covers coastal waters of the Black Sea (along the shore of Bulgaria, Romania, and Ukraine), the Sea of Azov, and the Caspian Sea. Single records of the species are known from the Danube in Hungary (Guti 1999). In waters of Ukraine, the species occurs in lakes of the Danube Delta area (Kytay, Katlabug, Yalpug and Kagul), in seaside waters of the Danube Delta (Movchan et al. 2003), in the Dnister Estuary, and rarely along the coast from the Dnister Estuary to the Grygorivsky Estuary (in some years during spring desalination) (Vynogradov 1960; Zambriborshch et al. 1995). Earlier the species was recorded in the Tiligul (Shekk 2004), Berezansky, and Dnipro-Bug Estuaries (Pinchuk 1968; Movchan et al. 2003), and rarely in the Kerch Strait (Shaganov \& Milovanov 2005). In the Sea of Azov, the species is widely distributed and also occurs in Lake Syvash (Demchenko 2005).

\section{Genus Proterorhinus Smitt, 1899}

Until recently, the genus was considered monotypic with a polymorphic species Proterorhinus marmoratus (Pallas, 1814). Results of genetic studies (Slynko et al. 2012; Sorokin et al. 2011) indicate that the Ponto-Caspian Basin is inhabited by two species of this genus: Pr. marmoratus represented by populations in waters of the Black Sea, and Pr. semilunaris inhabiting saline and freshwaters of this basin. In addition, the latter species also includes the earlier known species Pr. nasalis and Pr. semipellucidus. The composition of the genus remains dubious and needs further clarification, although currently it comprises 4-5 (?) species that inhabit fresh, brackish, and saline waters of the Azov-Black Sea Basin, the Caspian Sea, as well as the north-eastern part of the Aegean Sea. In this review, we follow the international database Fishbase (Froese \& Pauly 2019) in which all these species are considered valid. Thus, in waters of Ukraine, four species of the genus occur.

Proterorhinus marmoratus (Pallas, 1814)

A species of the Ponto-Caspian faunal complex. Its geographic range is yet to be clarified. In saline and brackish waters of Ukraine, the species occurs in the coastal zone of the Black Sea near Zmiinyi Island (Snigiryov 2008), in seaside waters of the Danube Delta (Balatskiy \& Voloshkevich 2005), along the coast of the Danube-Dnister interfluve to the Grygorivsky Estuary, including the Budatsky, Dnister, Tiligul (Shekk 2004), Berezansky, and Dnipro-Bug Eastuaries, as well as in Yahorlyk, Tendra, and Dzharylhach Bays (Pinchuk 1987; Pinchuk \& Tkachenko 1996; Movchan 2000; Manilo 2009a). The species is known from nearby to Sevastopol and quite rarely also occurs along the southern coast of the Crimea to the Kerch Strait (Bogutskaya \& Naseka 2004; Shaganov \& Milovanov 2005; Shaganov 2009). The species was recorded in the southern part of the Sea of Azov and in Lake Syvash, in the Utlyuk and Molochny Estuaries, as well as near Berdiansk Spit (Demchenko \& Mityai 2001; Diripasko et al. 2011; Demchenko et al. 2005).

Proterorhinus nasalis (De Filippi, 1863)

A species of the Ponto-Caspian faunal complex. Its geographic range covers the basins of the Sea of Azov and the Caspian Sea. In Ukraine, the species occurs in the coastal desalinated zone of the Sea of Azov and is known from the Molochny Estuary, near Obitochna and Berdiansk Spits, as well as from Lake Syvash (Movchan 2011). The species' range needs to be clarified. 
Proterorhinus semilunaris (Heckel, 1837)

A species of the Ponto-Caspian faunal complex. It is distributed in estuaries of the western and north-western parts of the Black Sea and in rivers that flow into them. The species is known in the Danube from its mouth to Central and Western Europe (Manne \& Poulet 2008; Manne et al. 2013), in the basin of the Dnister, in the Southern Bug and Dnipro Rivers, in the lower course of the Marytsia and Struma Rivers that flow into the eastern part of the Aegean Sea (Kottelat \& Freyhof 2007; Froese \& Pauly 2019), as well as in the basin of the Vistula to its mouth (Grabowska et al. 2008). The species was brought to lakes and rivers of North America with ballast waters (Stepien \& Tumeo 2006; Neilson \& Stepien 2009).

Proterorhinus tataricus Freyhof et Naseka, 2007

A species of the Ponto-Caspian faunal complex. A strict endemic of freshwaters of the Crimea. It is known from the Chorna River (Freyhof \& Naseka 2007), which flows into Sevastopol Cove.

\section{Subfamily Gobiinae}

\section{Genus Aphia Risso, 1827}

A monotypic genus.

\section{Aphia minuta (Risso, 1810)}

A species of the Atlantic-Mediterranean faunal complex. Distributed in the eastern Atlantic from the Scandinavian Peninsula to Morocco. Also inhabits the Mediterranean (not recorded along the northern coast of Africa), Adriatic, Aegean, Marmara, and Black Seas, and occurs in the southern part of the Sea of Azov (Svetovidov 1964; Vasileva 2007). In waters of Ukraine, the species was recorded in seaside waters of the Danube Delta (Chepurnov et al. 1954), in the Sasyk Estuary before its separation from the sea by a dam and desalination by waters from the Danube (Smirnov \& Tkachenko 2007), along the seashore in the north-western part of the Black Sea to Odesa (Kvach 2015), in Karkinit Bay in the area of Zernov's Phyllophora Field Botanical Sanctuary, in Yahorlyk and Tendra Bays, near the Tarkhankut Peninsula (Vynogradov 1960), near Zmiinyi Island (Snigiryov 2008), in coastal waters of north-western Crimea (Chesalin et al. 2004; Karpova 2009) and Karadag (Vinogradov 1949), in the Kerch Strait (Shaganov \& Milovanov 2005), and in the southern part of the Sea of Azov (Diripasko et al. 2011). One of the few pelagic species of the family.

\section{Genus Chromogobius de Buen, 1930}

The genus consists of three species distributed in the eastern Atlantic and in the Mediterranean and Black Seas. Two species occur in waters of Ukraine.

\section{Chromogobius quadrivittatus (Steindachner, 1863)}

A species of the Atlantic-Mediterranean faunal complex. Its geographic range covers coastal waters of the northern (Spain, France, Italy, Croatia) and eastern parts of the Mediterranean Sea (Adib 2005). Also occurs in the Sea of Marmara, the Aegean (Bilecenoglu et al. 2014) and the Black Seas. A highly rare species in every part of the range. In the Black Sea, it was earlier also known near the coast of the Caucasus (Pinchuk 1987), where by know has entirely disappeared, as well as in Varna Bay (Georgiev 1961). A single record of the species during fish kills near Odesa is reported by A. K. Vinogradov and S. A. Khutornoy (2013), although the specimen was not preserved and only its photograph was published. In waters of Ukraine, the species was first recorded in underwater karst caves of Cape Tarkhankut (Kovtun 2013). In 2015, a number of specimens, including juveniles, were found in Martynova Cove (Sevastopol, Crimea) (Boltachev \& Karpova 2016), and in Kozacha Cove in 2016 (Boltachev \& Karpova 2017). According to the latest data, the species was also revealed in underwater caves of Bulgaria north of Varna Bay nearby to the border with Romania. 


\section{Chromogobius zebratus (Kolombatović, 1891)}

A species of the Atlantic-Mediterranean faunal complex. A recent invader of the Mediterranean. It is known from several localities of the northern (Spain, France, Italy) (Colombo \& Langeneck 2013) and eastern parts of the Mediterranean (Lebanon, Turkey) (Engin \& Dalgiç 2008), Adriatic (Croatia, Montenegro), and Aegean Sea (Greece) (Miller 1986). A rare and non-abundant species. In the Black Sea, it was first recorded in waters of Ukraine in underwater caves of Cape Tarkhankut (Kovtun \& Karpova 2014; Boltachev \& Karpova, 2014, 2017).

\section{Genus Gammogobius Bath, 1971}

A monotypic genus.

\section{Gammogobius steinitzi Bath, 1971}

A species of the Atlantic-Mediterranean faunal complex. Known from several localities of the northern part of the Mediterranean Sea: off the coast of France (Dufour et al. 2007), near Ibiza, (Scsepka \& Ahnelt 1999), in the north of the Tyrrhenian Sea near Giglio Island, Italy (Ahnelt et al. 1998), in the north of the Adriatic Sea near Krk, Croatia (Kovačić 1999), as well as near Crete, Greece (Kovačić et al. 2011). A rare and non-abundant species. It is known in the Black Sea only in waters of Ukraine from marine underwater karst caves of the Tarkhankut Peninsula near Malyi Atlesh tract (Kovtun 2012; Kovtun \& Manilo 2013).

\section{Genus Gobius Linnaeus, 1758}

The genus includes 28 species distributed in the Indo-West Pacific, Atlantic Ocean, Mediterranean Sea, Black Sea, and the Sea of Azov. In waters of Ukraine, currently seven species are known.

\section{Gobius bucchichi Steindachner, 1870}

A species of the Atlantic-Mediterranean faunal complex. Distributed in the eastern Atlantic from the south of Portugal to the coasts of Morocco. Also occurs in the Mediterranean Basin: in the Adriatic, Aegean, and Marmara Seas. In the Black Sea, the species is distributed along the coasts of Turkey, the Caucasus, the Crimea, and Bulgaria (Vasileva 2007). In Ukraine, the species inhabits coastal waters along the western shore of the Crimea near Cape Tarkhankut and Sevastopol (Boltachev \& Karpova 2012b; Manilo 2014).

\section{Gobius cobitis Pallas, 1814}

A species of the Atlantic-Mediterranean faunal complex. Distributed in the eastern Atlantic from the English Channel to Morocco, as well as in the Mediterranean Basin (Adriatic, Aegean, and Marmara Seas). In the Black Sea, the species occurs near the coasts of the Crimea, the Caucasus, Turkey, Romania, and Bulgaria. Absent in the Sea of Azov (Vasileva 2007). In waters of Ukraine, it was recorded near Cape Tarkhankut (Malyi Atlesh tract), along the southern coast of the Crimea from Sevastopol to Karadag and Feodosia (Boltachev 2003; Gordina et al. 2004; Shaganov 2009). In the north-western part of the Black Sea, it was discovered near Zmiinyi Island (Manilo 2009a).

\section{Gobius couchi Miller et El-Tawil, 1974}

A quite rare Atlantic-Mediterranean species. A recent invader of the Mediterranean Basin. It was described from coastal waters of Great Britain (Miller \& El-Tawil 1974) and later recorded near south-western and northern Ireland (Minchin 1988; Costello 1992). Later, the species was found in the Mediterranean Basin: in 1996-1997, near the coast of Croatia (Kovačić 2001); in 1999, in the Tyrrhenian Sea near Ischia (Stefanni \& Mazzoldi 1999); in 2004, in the Ionian Sea near Corfu (Šanda \& Kovačić 2009); in 2007, in the Aegean Sea, in the southern part of the Dardanelles (Ozen et al. 2009); in 2009, in the Ligurian Sea (Liu et al. 2009); in 2010, near Crete (Kovačić et al. 2011); in 2011, near Malta (Kovačić et al. 2013). In the Black Sea, the species was recorded in 2015-2016 only in waters of Ukraine in Kozacha and Karantynna Coves (Karpova \& Boltachev 2018), where the species has completely adapted to conditions of the south-western coast of the Crimea. 
A species of the Atlantic-Mediterranean faunal complex. A recent invader to the Mediterranean. Widely distributed in the eastern Atlantic from south-western Ireland to Morocco and Senegal, as well as in seas of the Mediterranean Basin (Adriatic, Aegean, Marmara Seas, and the Bosporus) and in the Black Sea (Golani et al. 2006). Its first records in the Black Sea are confined to coastal waters of Ukraine near Sevastopol in Martynova Cove from 2002. Later, in 2007, a number of specimens were caught off the coast and in coves of Sevastopol (Boltachev et al. 2009a; Boltachev \& Karpova 2014). About the same time, the red-mouthed goby was recorded near the coast of Turkey (Engin et al. 2007). Since then a stable tendency of increase in abundance and distribution has been observed along the south-western coast of the Crimea to Laspi Cove (Boltachev \& Karpova 2014).

Gobius niger Linnaeus, 1758

A species of the Atlantic-Mediterranean faunal complex. Widely distributed in waters of the eastern Atlantic from the coast of Norway and the Baltic Sea to Morocco, including the Canary Islands. A common species in the Mediterranean, Adriatic, Aegean, and Marmara Seas. In the Black Sea, the species occurs along the entire coast (Vasileva 2007). S. P. Volovik and S. A. Chikhachev (1998) noted the expansion of the species' range in the Sea of Azov to its northern parts. In waters of Ukraine, the species occurs near Zmiinyi Island (Snigiryov 2008), in seaside waters of the Danube Delta (also occurred in the Sasyk Estuary before its desalination (Smirnov \& Tkachenko 2007)), along the coast from the Danube-Dnister interfluve to the Grygorivsky Eastuary including Shagan and Dnister shoalbanks, in the Budak Estuary, in the southern part of the Dnister Estuary (Manilo 2009a), in the Tiligul Estuary (Shekk 2004), at the mouth of the Dnipro-Bug Estuary, as well as in Tendra, Yahorlyk, Dhzarylhach, and Karkinit Bays (Pinchuk \& Tkachenko 1996) and near the coast of the Crimea (Gordina et al. 2004; Shaganov 2009).

Gobius paganellus Linnaeus, 1758

A species of the Atlantic-Mediterranean faunal complex. Distributed in the eastern Atlantic from the western coast of Scotland to Senegal, including the Azors, the Canary Islands, and Madeira. Also occurs in the Mediterranean, Adriatic, Aegean, and Marmara Seas. Throught the Suez Canal, it penetrated the Red Sea. In the Black Sea, the species is known from coastal waters of Bulgaria, Turkey, the Caucasus, and the south of the Crimea (Vasileva 2007). In waters of Ukraine, the species occurs near Zmiinyi Island (Snigirov et al. 2018), Sevastopol, and the area of the Tarkhankut Peninsula, as well as along the southern coast of the Crimea to Feodosia where it is a rare species (Boltachev 2003; Shaganov 2009).

Gobius xanthocephalus Heimer et Zander, 1992

A species of the Atlantic-Mediterranean faunal complex. A recent invader of the Mediterranean Sea. Inhabits coastal waters of the eastern Atlantic along the shores of Portugal (Almeida \& Arruda 1998) and the Canary Islands (Wirtz \& Herrera 1995). In the Mediterranean Sea, it is known off the coast of France (Heimer \& Zander 1992). The species' occurrence in the central and eastern parts of the Mediterranean Sea (from Italy to Turkey) is debatable (Louisy 2002). It is a rare species in the Black Sea, where it was recorded in its eastern part near Abkhazia (Vasileva \& Bogorodskii 2004). In waters of Ukraine, the species was found in the Crimea in coves of Sevastopol (Boltachev et al. 2009a) and near Cape Tarkhankut (Karpova \& Saksahanskyy 2011).

\section{Genus Knipowitschia Iljin, 1927}

The genus includes 17 species distributed in basins of the Mediterranean, Black, and Caspian Seas. Two species are known in saline, brackish, and freshwaters of Ukraine.

Knipowitschia caucasica (Berg, 1916)

A species of the Atlantic-Mediterranean faunal complex. The most widely distributed representative of the genus occurring in basins of the Sea of Azov, the Black, Caspian, Ionian, Adriatic, Aegean, and Marmara Seas (Economidis \& Miller 1990; Ahnelt et al. 1995). In the 1950s, it was accidently 
introduced in the Aral Sea, where by now its population diasappeared. In the Black Sea, the species occurs in the western and northern parts along the coasts of Bulgaria (in lakes near Burgas and in the lower course of rivers that flow into them) (Vassilev \& Pehlivanov 2005), Romania (Banarescu 1964), and further to the Kerch Peninsula and the coast of the Caucasus. In marine and brackish waters of Ukraine, the species was recorded in the Danube Delta (Balatskiy \& Voloshkevich 2005), in the Sasyk Estuary before its separation from the sea by a dam (Smirnov \& Tkachenko 2007), along the shore of the Danube-Dnister interfluve (Chepurnov 1958), in the Budatsky (Manilo 2014), Tiligul (Shekk 2004), and Berezansky Estuaries, in Tendra Bay (Vinogradov et al. 1967; Manilo 2009a), in the Kerch Strait, in the Eastern Syvash, in the Utlyuk and Molochnyi Estuaries (Demchenko et al. 2005), and in mouths of small rivers (Diripasko et al. 2011). According to A. V. Pankov (Pankov 2007), the species is actively expanding its range to the north in the Dnipro River. It was also recorded in the upper course of the Siversky Donets (tributary of the Don) within Kharkiv Oblast, Ukraine (Shandikov et al. 2009). Knipowitschia longecaudata (Kessler, 1877)

A species of the Atlantic-Mediterranean faunal complex. Distributed sporadically in the western and south-western parts of the Black Sea (Bulgaria, Romania, and Ukraine), in the southern and eastern parts of the Sea of Azov, and in the northern part of the Caspian Sea (Troitskiy \& Tsunikova 1988). It was also recorded in Turkey in Lake Manyas (Turan et al. 2005). In waters of Ukraine, the species was discovered in lakes of the Danube Delta area (Zelenin \& Vladimirov 1975), in the lower part of the Danube Delta (Balatskiy \& Voloshkevich 2005), in the Sasyk (Moshu 2006; Smirnov \& Tkachenko 2007), Dnister, Tiligul (Shekk 2004), and Dnipro-Bug Estuaries and in the lower course of rivers that flow into them. In P. J. Miller's opinion (Miller 2004), records of the species in the Crimea near Sevastopol and Yalta and in the Yahorlyk Esturary (Vinogradov 1960) possibly belong to Pomatoschistus marmoratus. The only specimen was caught in the estuary zone of the Chorna River near Sevastopol (Boltachev \& Karpova 2012a). In the area of the Kerch Strait, records of the species were reported from desalinated estuaries of the Kuban region. It was also found in the North Crimean Canal (Karpova 2009). A semipelagic species.

\section{Genus Millerigobius Bath, 1973}

A monotypic genus.

\section{Millerigobius macrocephalus (Kolombatovič, 1891)}

A species of the Atlantic-Mediterranean faunal complex. A recent invader of the Mediterranean Basin. It was known as an endemic of the Aegean and Adriatic Seas (Miller 1986; Golani et al. 2006; Kovačić 2008). It was also found near Ibiza (Fischer et al. 2007), Corsica, and near the entrance to the Dardanelles (Bogorodsky et al. 2010). A rare species. It was not recorded in the Black Sea earlier. In waters of Ukraine, the species was first discovered in April 2009 in Sevastopol Cove during inspection of artificial mussel collectors installed at the mouth of the cove (Boltachev et al. 2010). By now, the species has formed here a separate population.

\section{Genus Pomatoschistus Gill, 1863}

The genus includes 14 species that inhabit the coastal zone from the north-eastern Atlantic to the Black Sea and Sea of Azov. Three species are known in marine and brackish waters of Ukraine.

\section{Pomatoschistus bathi Miller, 1982}

A species of the Atlantic-Mediterranean faunal complex. The native range of the species covers the Mediterranean, Aegean, and Marmara Seas. In the Black Sea, it is known near the coast of Abkhazia (Vasileva \& Bogorodskii 2004), and near the Black Sea coast of Russia (Vasileva 2007) and Bulgaria (Vassilev et al. 2012). In marine waters of Ukraine, the species was first recorded in the early 2000s in coves of Sevastopol and along the southern coast of the Crimea from Cape Sarych to Cape Tovsty (Boltachev \& Karpova 2010). Currently, the species is abundant in coves of Sevastopol and Lake Donuzlav, as well as near the Tarkhankut Peninsula (Eremeev et al. 2012). Also occurs along the 
southern coast of the Crimea (it was recorded in 2013 in the Karadag Nature Reserve) (Boltachev et al. 2016) and in Karkinit Bay (Prishchepa et al. 2018). In A. R. Boltachev and E. P. Karpova's (2010) opinion, a self-maintaining population of the species has formed in the coastal zone of the Crimea.

Pomatoschistus marmoratus (Risso, 1810)

A species of the Atlantic-Mediterranean faunal complex. Inhabits coastal waters of the eastern Atlantic from Great Britain to the Bay of Biscay, Portugal, and Spain (Froese \& Pauly 2019). Also occurs in the Mediterranean, Aegean, and Marmara Seas, and in the Suez Canal. It was introduced to Lake Qarun, Egypt (Vasileva 2007). In the Black Sea and Sea of Azov, it is widely distributed along almost the entire coast. In waters of Ukraine, it occurs along the entire coast in marine waters, estuaries, saline and brackish lakes (Gordina et al. 2004; Shekk 2004; Demchenko 2005; Shaganov \& Milovanov 2005; Manilo 2009a; Movchan 2011).

Pomatoschistus minutus (Pallas, 1770)

A species of the Atlantic-Mediterranean faunal complex. Inhabits coastal waters of the eastern Atlantic from the coast of Norway to the southern part of the Iberian Peninsula; also common in the Mediterranean, Aegean, Marmara, and Black Seas (Miller 1986; Vasileva 2007). In waters of Ukraine, it was recorded in coastal waters of Zmiinyi Island (Pinchuk \& Savchuk 1982), in seaside waters of the Danube Delta, along the coast of the Danube-Dnister interfluve, in the Budatsky Estuary, in the lower part of the Dnister Estuary, in Odesa Bay (Kvach 2015), at the mouth of the Berezansky Estuary, in Yahorlyk, Tendra, and Dzharylhach Bays (Vynogradov 1960; Pinchuk \& Tkachenko 1996; Movchan 2000), as well as in the Crimea in Lake Donuzlav (Boltachev \& Zuyev 1999), near Sevastopol (Karpova 2009), and in the Kerch Strait. The species was not noted for the Sea of Azov until the mid-1950s, although in the mid-1970s it has expanded its range to the northern part of sea (Pinchuk \& Savchuk 1982). Eventually, the species was included into the checklist of fishes of the Sea of Azov (Diripasko et al. 2011).

\section{Genus Zebrus de Buen, 1930}

A monotypic genus.

Zebrus zebrus (Risso, 1827)

A species of the Atlantic-Mediterranean faunal complex. Distributed in the Mediterranean Sea except for small areas of the northern coast of Africa (Kovačić et al. 2005; Bogorodsky et al. 2010). In the eastern Atlantic, it was recorded near the coast of Spain in the southern part of the Iberian Peninsula (Froese \& Pauli 2019). A recent invader of the Mediterranean Sea. In 2007, a mature specimen was caught in the Black Sea off the coast of Turkey near Cape Jason (Kovačić \& Engín 2009). In waters of Ukraine, the species was first recorded near the shore of the Crimea at mussel collectors in Sevastopol Cove, where since 2009 co-occurs with M. macrocephalus allowing to suggest that the species has naturalised in the Crimea (Manilo et al. 2013a; Karpova et al. 2015).

\section{Genus Zosterisessor Whitley, 1935}

A monotypic genus.

\section{Zosterisessor ophiocephalus (Pallas, 1814)}

A species of the Atlantic-Mediterranean faunal complex. Distributed along the northern and south-western coast of the Mediterranean Sea, as well as in the Aegean and Marmara Seas (Miller 1986). Its records in the Bay of Biscay are dubious (Pinchuk et al. 2004b). In the Black Sea, the species is known along almost the entire shore except for the central part of the northern coast of Turkey, and it is very rare near the southern coast of the Crimea. In the Sea of Azov, it is distributed from the south-western to the northern coast (Demchenko et al. 2005). In waters of Ukraine, the species occurs from seaside waters of the Danube Delta to the Kerch Strait, including all estuaries and bays. In the Sasyk Estuary, the species disappeared after its separation from the sea by a dam (Smirnov \& Tkachenko 2007). 


\section{Discussion}

In summary, we can note that the true gobies are currently represented in Ukraine by 38 species of 17 genera. The fauna of the family Gobiidae includes representatives of the Ponto-Caspian (20 species, $52.6 \%$ of the total number of species of the family in Ukraine) and Atlantic-Mediterranean (18 species, $47.4 \%$ ) faunal complexes (see Table 1 ).

Table 1. The current species composition of the family Gobiidae of waters of Ukraine and the faunal complexes to which they belong

Таблиия 1. Сучасний видовий склад родини Gobiidae водойм України та їх належність до фауністичних комплексів

\begin{tabular}{ll}
\hline \multicolumn{1}{c}{ Species } & Faunal complex \\
\hline Benthophiloides brauneri & PC \\
Benthophilus magistri & PC \\
B. nudus & PC \\
B. stellatus & PC \\
Caspiosoma caspium & PC \\
Neogobius fluviatilis & PC \\
N. melanostomus & PC \\
Babka gymnotrachelus & PC \\
Mesogobius batrachocephalus & PC \\
Ponticola cephalargoides & PC \\
P. eurycephalus & PC \\
P. kessleri & PC \\
P. platyrostris & PC \\
P. ratan & PC \\
P. syrman & PC \\
Proterorhinus marmoratus & PC \\
P. nasalis & PC \\
P. semilunaris & PC \\
P. tataricus & PC \\
Aphia minuta &
\end{tabular}

\begin{tabular}{lcc}
\hline \multicolumn{1}{c}{ Species } & Faunal complex \\
\hline Chromogobius quadrivittatus $^{\star}$ & & AM \\
C. zebratus & & AM \\
Gammogobius steinitzi $^{\star}$ ? & & AM \\
Gobius bucchichi $_{\text {G. cobitis }}$ & AM \\
G. couchi & & AM \\
G. cruentatus & & AM \\
G. niger & & AM \\
G. paganellus & AM \\
G. xanthocephalus & & AM \\
Knipowitschia caucasica & & AM \\
K. longecaudata & & AM \\
Millerigobius macrocephalus & \\
Pomatoschistus bathi & & \\
P. marmoratus & PC & AM \\
P. minutus & & AM \\
Zebrus zebrus $^{\star}$ & & AM \\
Zosterisessor ophiocephalus & & AM \\
\hline Total (n) & & AM \\
(\%) & & AM \\
\hline
\end{tabular}

Note. Faunal complexes: PC - Ponto-Caspian, AM - Atlantic-Mediterranean, ${ }^{*}$ - recent immigrant species; ${ }^{\star}$ ? - time of appearance unknown; endemic species are given in bold.

Among species of the Atlantic-Mediterranean complex, a group of recent invaders can be highlithed, which appeared in the Black Sea in the early 2000s (Chromogobius zebratus, Gobius couchi, G. cruentatus, G. xanthocephalus, Millerigobius macrocephalus, Pomatoschistus bathi, and Zebrus zebrus). This is directly related to the natural permanent process of Mediterranization. The time of appearance of two species (Chromogobius zebratus and Gammogobius steinitzi) remains unknown. By now, near the coast of Ukraine and in coves of the Crimea such species as C. quadrivittatus (according to records of juveniles in coves of Sevastopol), G. cruentatus, M. macrocephalus, and P. bathi have fully naturalised. Four species of the family Gobiidae are endemic to Ukraine: Benthophilus magistri, B. stellatus, P. platyrostris, and Proterorhinus tataricus.

\section{References}

Adib, S. 2005. Check-list of Bony Fish Collected from the Coast of Syria. Turkish Journal of Fisheries and Aquatic Sciences, 5: 99-106.

Ahnelt, H., P. Bănărescu, R. Spolwind, Á. Harka, H. Waidbacher. 1998. Occurrence and distribution of three gobiid species (Pisces: Gobiidae) in the middle and upper Danube region - example of different dispersal patterns? Biologia, 53: 661-674.

Ahnelt, H., J. Herler, S. Scsepka. 1998. First records of two rare Mediterranean Gobiidae in the northern Tyrrhenian Sea. Cybium, l (22): 83-186.

Ahnelt, H., P. G. Bianco, H. Schwammer. 1995. Systematics and zoogeography of Knipowitschia caucasica (Teleostei: Gobiidae) based on new records from the Aegean Anatolian area. Ichthyol. Explor. Freshw., 6 (1): 49-60.

Almeida, A. J., L. M. Arruda. 1998. Gobius xanthocephalus Heimer and Zander, 1992 in Portuguese waters (Pisces: Gobiidae). Arq. Mus. Bocage. Nov. Ser., 3 (5): 205-212. 
Ambroz, A. I. 1956. Ryby Dnepra, Yuzhnogo Buga i Dneprovsko-Bugskogo limana. Kiev: Izd-vo AN USSR. 1-405. (In Russian)

Balatskiy, K. L., A. N. Voloshkevich. 2005. Ryby Dunayskogo biosfernogo zapovednika. Del'ta i chelovek. Ekol. gazeta Pridunays'kogo krayu. 30 grud. № 22-24 (81-83): 9. (In Russian)

Bănărescu, P. 1964. Pisces-Osteichthyes (Pestii Ganoizi si Ososii) (Fauna Republicii Populare Romine). Bucharest: Acad. Republicii Populare Romine, 13: 1-962.

Beling, D. E. 1927. Materialy do ikhtiofauny r. Pivdennyy Bog. Zbirn. prats' Dnipr. biol. stantsiyi, 2: 334-356. (In Ukrainian)

Berg, L. S. 1949. Freshwater fishes of the USSR and adjacent countries. Chast 3. 4th ed. Izdatelstvo AN SSSR. Moskva, Leningrad, 929-1382. (In Russian)

Bilecenoglu, M, M. Kaya, B. Cihangir, E. Cicek. 2014. An updated checklist of the marine fishes of Turkey. Turk. J. Zool., 38: 901-929.

Bogorodsky, S., M. Kovačić, O. Ozen, M. Bilecenoglu. 2010. Records of two uncommon goby species (Millerigobius macrocephalus, Zebrus zebrus) from the Aegean Sea. Acta Adriat., 51 (2): 217-222.

Bogutskaya, N. G., A. M. Naseka, V. S. Boldyrev. 2004. Bychki Neogobiinae (Teleostei: Gobiidae) v ekosistemakh Yevrazii i severoamerikanskikh Velikikh ozer. Biological invasions in aquatic and terrestrial ecosystems. Moscow: KMK Scientific Press Ltd., 297-320. (In Russian)

Boldyrev, V. S., N. G. Bogutskaya. 2007. Revision of the tadpole-gobies of the genus Benthophilus (Teleostei: Gobiidae). Ichthyol. Explor. Freshwaters, 18 (1): 31-96.

Boltachev, A. R. 2003. Taksonomicheskoye raznoobraziye. Sovremennoye sostoyaniye bioraznoobraziya pribrezhnykh vod Kryma (Chernomorskiy sektor). Ikhtiofauna chernomorskogo poberezhya Kryma. Sevastopol: EKOSI-Gidrofizika: 364-379. (In Russian)

Boltachev, A. R., E. D. Vasileva, O. N. Daniluk. 2007. First Finding of the Stripe Tripletooth Goby Tridentiger trigonocephalus (Perciformes, Gobiidae) in the Black Sea (the estuary of the Chernaya River, Sevastopol Bay). J. Ichthyology, 47 (9): 802-805.

Boltachev, A. R., E. P. Karpova, O. N. Danilyuk. 2009a. Findings of New and Rare Fish Species in the Coastal Zone of the Crimea (the Black Sea). Journal of Ichthyology, 49 (4): 277-291.

Boltachev, A. R., E. P. Karpova, O. N. Danilyuk. 2009b. The First Find of the Brauner's Tadpole-goby Benthophiloides brauneri (Perciformes, Gobiidae) in the Sea of Azov. Morskyy ekolohichnyy zhurnal, 8 (3): 14. (In Russian)

Boltachev, A. R., E. P. Karpova. 2010. Bath's goby Pomatoschistus bathi (Perciformes, Gobiidae) is a new species for the ichthyofauna of the Crimean coast of the Black Sea. Morskyy ekolohichnyy zhurnal, 9 (2): 57. (In Russian)

Boltachev, A. R., E. P. Karpova. 2012a. The ichthyofauna of the Sevastopol coastal zone (the Black Sea). Mors'kyy ekolohichnyy zhurnal, 2 (11): 10-27. (In Russian)

Boltachev, A. R., E. P. Karpova. 2012b. Marine Fishes of the Crimean peninsula. Biznes-Inform, Simferopol, 1-224. (In Russian)

Boltachev, A. R., E. P. Karpova, V. K. Machkevskiy. 2010. The naturalization of Miller's goby, Millerigobius macrophthalmus (Perciformes, Gobiidae) in the Sevastopol bay of the Black Sea. Morskyy ekolohichnyy zhurnal, 9 (1): 32. (In Russian)

Boltachev, A. R., E. P. Karpova. 2014. Faunistic Revision of Alien Fish Species in the Black Sea. Russian Journal of Biological Invasions, 3: 2-25.

Boltachev, A. R., E. P. Karpova. 2016. Redkiye, uyazvimyye i ischeznuvshiye ryby Sevastopolskogo regiona. Nauchnyye zapiski prirodnogo zapovednika "Mys Martyan". Vyp. 7. Fauna i zhivotnyy mir, 251-264. (In Russian)

Boltachev, A. R., E. P. Karpova. 2017. Marine Fishes of the Crimean peninsula. 2nd edition: revised and enlarged. Simferopol, Biznes-Inform, 1-376. (In Russian)

Boltachev, A. R., G. V. Zuyev. 1999. Sostav i ekologicheskaya struktura ikhtiofauny limana Donuzlav (severozapadnyy Krym). Voprosy ikhtiologii, 39 (1): 57-63. (In Russian)

Boltachev, A. R., V. M. Yurachno. 2002. New evidence of the continuing mediterranization fish fauna of the Black Sea. Voprosy Ikhtiologii, 42 (6): 744-750. (In Russian)

Boltachev, A., E. Karpova, I. Vdodovich. 2016. Distribution, Biological and Ecological Characteristics of Alien Species Pomatoschistus bathi Miller, 1982 (Gobiidae) in the Black Sea. Turkish Journal of Fisheries and Aquatic Sciences, 16: 113-122.

Borcherding J., S. Staas, S. Krüger, M. Ondračková, L. Šlapanský, P. Jurajda. 2011. Non-native gobiid species in the lower River Rhine (Germany): recent range extensions and densities. Journal of Applied Ichthyology, 27: $153-155$.

Bulakhov, V. L., R. O. Novitsky, O. E. Pakhomov, O. O. Khrystov. 2008. Biologichne riznomanittya Ukrayiny. Dnipropetrovska oblast. Kruhloroti (Cyclostomata). Ryby (Pisces). Dnipropetrovsk: Vyd-vo Dnipropetrov. nats. un-tu, 1-304.

Chepurnov, V. S. 1958. Biologicheskiye osobennosti i promysel nekotorykh ryb severo-zapadnoy chasti Chernogo morya. Uchen. zap. Kishinev. un-ta, 32: 3-46. (In Russian)

Chepurnov, V. S., M. S. Burnashev, V. N. Dolgiy. 1954. Materialy po faune ryb severo-zapadnoy chasti Chernogo morya. Uchen. zap. Kishinev. un-ta. Ser. biol., 13: 3-15. (In Russian) 
Chesalin, M. V., G. V. Zuev, T. L. Chesalina. 2004. Transparent Goby Aphia minuta (Gobiidae) in the Pelagic Zone of Black Sea. J. Ichthyol., 44 (8): 632-636.

Colombo, M., J. Langeneck. 2013. The importance of underwater photography in detecting cryptobenthic species: new in situ records of some gobies (Teleostei: Gobiidae) from Italian Seas with ecological notes. Acta Adriat., 54 (1):101-110.

Costello, M. 1992. Abundance and spatial overlap of gobies (Gobiidae) in Lough Hyne, Ireland. Environ. Biol. Fish., 33: 239-248.

Danilkiewicz, Z. 1996. Babka łysa (gołogłowa), Neogobius gymnotrachelus (Kessler, 1857) Perciformes, Gobiidae) nowy gatunek w ichtiofaunie zlewiska Morza Bałtyckiego. Komun. Rybackie, 2: 27-29.

Danilkiewicz, Z. 1998. Babka szczupła, Neogobius fluviatilis (Pallas, 1811), Perciformes, Gobiidae nowy pontyjski element w ichtiofaunie zlewiska Morza Bałtyckiego. Fragm. faun., 41: 269-277.

Demchenko, N. A., P. M.Zabroda, V. O. Demchenko. 2005. Vydove riznomanittya rodyny Gobiidae v vodoymakh pivnichno-zakhidnoho Pryazovya. Nauk. zap. Ternopilskoho nats. pedahoh. un-tu im. V. Hnatyuka. Ser. Biolohiya. 4 (27). Spets. vyp. Hidroekolohiya: 67-69. (In Ukrainian)

Demchenko, V. A., I. S. Mityai. 2001. Current State of Some Mass Gobies (Gobiidae) from the Molochnyi Liman and Adjacent Areas of the Sea of Azov. Ekologiya morya, 56: 5-8. (In Russian)

Demchenko, V. O. 2005. Dynamika vydovoho skladu ryb Skhidnoho Syvashu u zv'yazku z transformatsiyeyu vodoymy. Nauk. zap. Ternopilskoho nats. pedahoh. un-tu im. V. Hnatyuka. Ser. Biolohiya, 4 (27). Spets. vyp. Hidroekolohiya: 65-67. (In Ukrainian)

Demchenko, V. O., A. I. Smirnov. 2009. Changes of ichthyodiversity of Sasyk, Tiligulsky, Molochny and Utlyuksky estuaries. Biologia ta Valeologia. Zb. nauk. pratz. Kharkiv, 11: 16-23. (In Ukrainian)

Diripasko, O. A., L. V. Izergin, K. V. Demyanenko. 2011. Ryby Azovskogo morya. Pod red. N. G. Bogutskoy. Berdyansk, Izd-vo OOO NPK Inter-M, 1-288. (In Russian)

Dufour, F., P. Guidetti, P. Francour. 2007. Comparaison des inventaires de poisons dans les aires marines protégées de Mediterranee: influence de la surface et de l'anciennete. Cybium, 31 (1): 19-31.

Economidis, P. S., P. J. Miller. 1990. Systematics of freshwater gobies from Greece (Teleostei: Gobiidae). J. Zool., 221: $125-170$.

Engin, S., D. Turan, M. Kovacic. 2007. First record of the redmouthed goby, Gobius cruentatus (Gobiidae), in the Black Sea. Cybium, 31: 87-88.

Engin, S., G. Dalgiç. 2008. First Record of Chromogobius zebratus (Gobiidae) for the Mediterranean Coast of Turkey. Turk. J. Zool., 32: 197-199.

Eremeev, V. N., A. R. Boltachev, B. G. Aleksandrov et al. 2012. Biological divercity of the coastal zone of the Crimean peninsula: problems, preservation and restoration pathways. NAS Ukraine, Inst. Biol. Southern Seas, Sevastopol, 1-92.

Eryilmaz, L. 2002. A new fish record for the Aegean Sea: round goby Neogobius melanostomus (Pallas, 1814) (Gobiidae). Israel J. Zool., 48: 251-252.

Fischer, S. T., R. A. Patzner, C. H. G. Müller, H. M. Winkler. 2007. Studies on the ichthyofauna of the coastal waters of Ibiza (Balearic Islands, Spain). Rostocker Meeresbiologische Beiträge, 18: 30-62.

Freyhof, J., A. M. Naseka. 2007. Proterorhinus tataricus, a new tubenose goby from Crimea, Ukraine (Teleostei: Gobiidae). Ichthyol. Explor. Freshw., 18 (4): 325-334.

Froese, R., D. Pauly. 2019. FishBase. World Wide Web electronic publication. www.fishbase.org, version $(08 / 2019)$.

Georgiev, J. M. 1961. An unknown goby for Bulgarian ichthiofauna - Relictogobius kryzanowskii. Izvestiya Central. nauchnoizsled. Inst. ribov. and fishing, 1: 141-145. (In Bulgarian)

Golani, D., B. Öztürk, N. Başusta. 2006. Fishes of the Eastern Mediterranean. Istanbul, Turkish Marine Research Foundation, 1-248.

Gordina, A. D., L. P. Salekhova, T. N. Klimova. 2004. Species composition of fish as an indicator of the current state of the coastal ecosystem of the southwestern shelf of Crimea. Morskyy ekolohichnyy zhurnal, 3 (2): 15-24. (In Russian)

Goroshko, O. A., V. N. Grishchenko, L. P. Zgerskaya ety al. 1989. Flora i fauna zapovednikov SSSR. Pozvonochnye zhivotnye Kanevskogo zapovednika (operativno-informatsionnyy material). M.: Proizv.-izd. komb. VINITI: 1-43. (In Russian)

Grabowska, J. 2005. Reproductive biology of racer goby Neogobius gymnotrachelus in the Wloclawski Reservoir (Vistula River, Poland). J. Appl. Ichthyol., 21: 296-299.

Grabowska, J., M. Grabowski. 2005. Indications on the diel feeding activity in early summer of racer goby Neogobius gymnotrachelus (Gobiidae) - a new invader in the Baltic Basin. J. Appl. Ichthyol., 21: 282-286.

Grabowska J., D. Pietraszewski, M. Ondračková. 2008. Tubenose goby Proterorhinus marmoratus (Pallas, 1814) has joined three other Ponto-Caspian gobies in the Vistula River (Poland). Aquatic Invasions, 3 (2): 261-265.

Grabowski M., K. Hupało, A. Bylak, K. Kukuła, J. Grabowska. 2016. Double origin of the racer goby (Babka gymnotrachelus) in Poland revealed with mitochondrial marker. Possible implications for the species alien/ native status. Journal of Limnology, 75 (1): 101-108.

Guti, G. 1999. Syrman-géb (Neogobius syrman) a Duna magyarországi szakaszán. Halászat, 92: 30-32.

Heimer, A., C. D. Zander. 1992. Le statut de Gobius auratus Risso, 1810 et description de Gobius xanthocephalus n. sp. de la Mediterranee (Teleostei, Gobiidae). Zool. Jahrb. Syst. (Jena), 119 (2): 291-313. 
Ilin, B. S. 1927. Opredelitel' bychkov (Fam. Gobiidae) Azovskogo i Chernogo morey (predvaritel'noye soobshcheniye). Tr. Azovo-Chernomor. nauch.-promysl. ekspeditsii, 2: 128-143. (In Russian)

Ilin, B. S. 1949. Kratkiy obzor chernomorskikh bychkov (Pisces, Gobiidae). Byull. Mosk. o-va isp. prirody, Otd. biologii, 54 (3): 16-30. (In Russian)

Jude, D. J. 2001. Round and tubenose gobies: 10 years with the latest Great Lakes phantom menace. Dreissena, $11(4): 1-14$.

Jurajda P., J. Černý, M. Polačik, Z. Valová, M. Janáč, R. Blažek, M. Ondračková. 2005. The recent distribution and abundance of non-native Neogobius fishes in the Slovak section of the River Danube. Journal of Applied Ichthyology, 21: 319-323.

Karpova, E. P. 2009. Rasprostranenye ryb semeystva bychkovykh (Gobiidae) v presnykh vodoemakh Kryma. Tezy II Mizhnar. ikhtiol. nauk.-prakt. konf. "Suchasni problemy teoretychnoyi ta praktychnoyi ikhtiolohiyi". Sevastopol: 60-62. (In Russian)

Karpova, E. P., A. R. Boltachev 2018. Distribution and Biological Characteristics of Couch's Goby Gobius couchi (Gobiidae), a New Species for the Black Sea. Journal of Ichthyology, 58 (3): 303-311.

Karpova, E. P., V.V. Saksahanskyy. 2011. Raspredelenye ryb semeystva bychkovykh (Gobiidae) u chernomorskoho poberezhya Kryma. Tezy IV Mizhnar. ikhtiol. nauk.-prakt. konf. "Suchasni problemy teoretychnoyi ta praktychnoyi ikhtiolohiyi" (Odesa, 7-11 ver. 2011 r.). Odesa: 117-118. (In Russian)

Karpova, E., A. Boltachev, S. Statkevich et al. 2015. Cryptobenthic fauna of the mussel farm's collectors. Turk. J. Fish. Aquat. Sci., 15 special issue: 511-521.

Kolyushev, I. I. 1949. Korotkyy vyznachnyk ryb Zakarpatskoyi oblasti URSR, Vyd-vo Uzhhorod. un-tu, Uzhhorod, 1-33. (In Ukrainian)

Kornis, M. S., N. Mercado-Silva, M. J. Vander Zanden. 2012. Twenty years of invasion: a review of round goby Neogobius melanostomus biology, spread and ecological implications. Journal of Fish Biology, 80: 235-285.

Kottelat, M., J. Freyhof. 2007. Handbook of European Freshwater Fishes. Cornol, Switzerland and Berlin, Germany, Kottelat M. and Freyhof J., 1-646.

Kovačić, M. 1999. Gammogobius steinitzi Bath, 1971, a fish new to the Adriatic Sea. Nat. Croat., 8 (1): 1-7.

Kovačić, M. 2001.The Kvarner population of Gobius couchi (Teleostei: Gobiidae), a fish new to the Adriatic fauna. Nat. Croat., 10: 1-10.

Kovačić, M., S. Bussotti, P. Guidetti. 2005. First record of the zebra goby, Zebrus zebrus (Pisces: Gobiidae), in the Ionian Sea. Ann. Ser. Hist. Nat., 15: 45-48.

Kovačić, M., 2008. The key for identification of Gobiidae (Pisces: Perciformes) in the Adriatic Sea. Acta Adriatica, 49 (3): 245-254.

Kovačić, M., S. Engín. 2009. First record of the zebra goby, Zebrus zebrus (Gobiidae), in the Black Sea. Cybium, 33 (1): 83-84.

Kovačić, M., M. Miletić, N. Papageorgiou. 2011. A first checklist of gobies from Crete with ten new records. Cybium, 35 (3): 245-253.

Kovačić, M., J. J. Bonello, J. Evans. 2013. Three new records of Gobiidae from Malta with morphology, coloration and identification of the smallest known juveniles of two small gobiid species. Cybium, 37: 233-239.

Kovtun, O. A. 2012. First records goby Gammogobius steinitzi Bath, 1971 (Actinopterygii, Perciformes, Gobiidae) in coastal grottoes of the western Crimea (Black Sea) (A preliminary report). Morskyy ekolohichnyy zhurnal, 11 (3): 56. (In Russian)

Kovtun, O. A. 2013. The new finding of a rare goby Chromogobius quadrivittatus (Actinopterygii, Perciformes, Gobiidae) in the marine underwater cave peninsula Tarhankut (Black Sea). Morskyy ekolohichnyy zhurnal, 13 (1): 18. (In Russian)

Kovtun, O. A., E. P. Karpova. 2014. Chromogobius zebratus (Kolombatovic, 1891) (Actinopterygii, Perciformes, Gobiidae) from marine underwater cave of Tarhankut peninsula (western Crimea), a species new for the Black Sea. Morskyy ekolohichnyy zhurnal, 13 (1): 72. (In Russian)

Kovtun, O. A., L. G. Manilo. 2013. Mediterranean Gammogobius steinitzi Bath, 1971 (Perciformes, Gobiidae) - a new representative of the Black Sea ichthyofauna. Acta Ichthyologica et Piscatoria, 43 (4): 307-314.

Kvach, Yu. 2015. The fish assemblage on the coastal shallow waters of the Gulf of Odessa and its diel changes. Studia Biologica, 9 (1): 191-200.

Kvach, Yu., S. Kudrenko, K. Mierzejewska. 2009. The First Record of Bighead Goby, Neogobius kessleri (Actinopterygii, Gobiidae), in the Khadzhibey Estuary, SW Ukraine. Vestnik zoologii, 43 (3): 286.

Liu, H. T. H., H. Ahnelt, G. A. C. Balma, G. B. Delmastro. 2009. First record of the rare gobiid fish Gobius couchi in the Ligurian Sea (north-western Mediterranean). Mar. Biodiversity Rec., 2, p. e135.

Louisy, P. 2002. Guide d'identification des Poissons Marins Europe de l'ouest et Mediterranee (Les Editions Eugen Ulmer).

Luzhnyak, V.A., A. A. Korneev. 2006. Modern Ichthyofauna of the Lower Don Basin and Anthropogenic Effects on the Drainage. Vopr. ikhtiologii, 46 (4): 503-511. (In Russian)

Lyashenko, O. F. 1952. Ryby ponyzzya Dunayu ta yikh promyslove znachennya. Tr. In-tu hidrobiolohiyi, 27: 28-66. (In Ukrainian)

Manilo, L. G. 2009a. Gobies Fishes (Gobiidae, Perciformes) of North-Western Part of the Black Sea and Adjoining Estuary Ecosystems. Zbirn. prats Zool. muzeyu, 40: 19-46. (In Russian) 
Manilo, L. G. 2009b. To Distribution of Some Species of the Gobies Family (Perciformes, Gobiidae) in the Waters of Ukraine. Vestnik zoologii, 43 (3): 275-281. (In Russian)

Manilo, L. G. 2011a. The Azov tadpole-goby, Benthophilus magistri (Gobiidae, Perciformes) - rare species in the ichthyofauna of Ukraine. Zbirn. pratz Zool. Muzeyu, 42: 92-99. (In Russian)

Manilo, L. G. 2011b. Features of Distributing Gobies Species (Actinopterygii, Perciformes) in Depending to the Salinity in Marine and Estuary Waters of the Azov-Black Sea Basin. Vestnik zoologii, 45 (3): 231-240. (In Russian)

Manilo, L. G., V. N. Peskov. 2012. Morphological Divergence and Diagnostic Characters of Ginger Goby Neogobius eurycephalus (Kessler, 1874) and Surman Goby N. cephalargoides Pinchuk, 1976 (Perciformes, Gobiidae). J. Ichthyol., 52 (1): 30-38. DOI: 10.1134/S0032945211050092.

Manilo, L. G., A. V. Didenko. 2013. A Record of the Ratan Goby, Ponticola ratan (Gobiidae, Perciformes), in the Dneprodzerzhinsk Reservoir (Dnieper River). Vestnik zoologii, 47(4): 335-341. DOI 10.2478/vzoo-20130035

Manilo, L. G., A. R. Boltachev, E. P. Karpova. 2013a. Gobiidae invasive species of the crimean marine waters. Zbirn. pratz Zool. Muzeyu, 44: 50-69. (In Russian)

Manilo, L. G., V. P. Onoprienko, I. S. Mitiay. 2013b. Recent data about Brauner's tadpole-goby, Benthophiloides brauneri (Gobiidae, Perciformes), in the Dnieper river. Zbirn. pratz Zool. Muzeyu, 44: 77-82. (In Russian)

Manilo, L. G. 2014. Ryby semeystva Bychkovye (Perciformes, Gobiidae) morskikh i solonovatykh vod Ukrainy. Naukova dumka, Kyiv, 1-243. (In Russian)

Manné S., N. Poulet, S. Dembski. 2013. Colonisation of the Rhine basin by non-native gobiids: an update of the situation in France. Knowledge and Management of Aquatic Ecosystems, 411.

Manné, S., N. Poulet. 2008. First record of the western tubenose goby Proterorhinus semilunaris (Heckel, 1837) in France. Knowledge and Management of Aquatic Ecosystems, 389, 03. DOI: 10.1051/kmae:2008009.

Markevych, O. P., Y. I. Korotkyy. 1954. Vyznachnyk prisnovodnykh ryb Ukrayiny. Radyanska shkola, Kyiv, 1-208. (In Ukrainian)

Miller, P. J. 1986. Gobiidae. Fishes of the North-Eastern Atlantic and the Mediterranean. Eds P. J. P. Whitehead, M.-L. Bauchot, J.-C. Hureau et al. UNESCO, Paris, 3: 1019-1085.

Miller, P. J. 2004. Knipovitschia longecaudata (Kessler, 1877). The Freshwater Fishes of Europe. Gobiidae 2. Wiebelsheim: AULA-Verlag GmbH. 8/2: 383-397.

Miller, P. J., M. Y. El-Tawil. 1974. A multidisciplinary approach to a new species of Gobius (Teleostei: Gobiidae) from southern Cornwall. J. Zool., 174: 539-574.

Minchin, D. 1988. Couch's goby, Gobius couchi (Teleostei: Gobiidae), from Irish waters. J. Zool., 33: 821-822.

Moshu, A. 2006. Materialy po vidovomu sostavu ryb limannogo ozera Sasyk. Akademiku L. S. Bergu - 130 let. Sb. nauch. statey. Bendery, Eco-TIRAS: 103-109. (In Russian)

Movchan, Yu. V. 2000. Spisok vidov ryb Jarylgachskogo zaliva. Biodiversity of the Jarylgach: Modern State and Ways for Conservation. Vestnik zoologii. Supplement. Special Issue: 182-184. (In Russian)

Movchan, Yu. V. 2001. Do ikhtiofauny baseynu nyzhn'oyi techiyi Dunayu v mezhakh Ukrayiny. Proceedings of the National Museun of Natural Hisrtory, 1: 38-141. (In Ukrainian)

Movchan, Yu. V. 2011. Fishes of Ukraine. Vyznachnyk dovidnyk. Zoloti vorota, Kyiv, 1-420. (In Ukrainian)

Movchan, Yu. V., A. V. Pankov, Yu. E. Rabtsevich. 2002. Finds of New Species of Fishes for the Middle and Upper Stream of the Southern Bug. Vestnik zoologii, 36 (5): 85-88. (In Ukrainian)

Movchan, Yu. V., L. G. Manilo, A. I. Smirnov, A. Ya. Shcherbukha. 2003. Katalog kollektsiy Zoologicheskogo muzeya NNPM NAN Ukrainy. Kruglorotye i ryby. Zoomuzey NNPM NAN Ukrainy, Kyiv, 1-342. (In Russian)

Neilson, M. E., C. A. Stepien. 2009. Escape from the Ponto-Caspian: Evolution and biogeography of an endemic goby species flock (Benthophilinae: Gobiidae: Teleostei). Mol. Phylogen. and Evol., 52: 84-102.

Nelson, J. S., T. C. Grande, M. V. H. Wilson. 2016. Fishes of the world. 5th edition. Hoboken, New Jersey. John Wiley \& Sons, $1-752$.

Nikolskiy, G. V. 1947. O biologicheskoy spetsifike faunisticheskikh kompleksov i znachenii yeye analiza dlya zoogeografii. Zoologicheskiy zhurnal, 26 (3): 221-232. (In Russian)

Nikolskyy, A. M. 1930. Vyznachnyk ryb Ukrayiny (Chornoho, Ozivskoho moriv i solodkykh vod). Derzh. vyd. Radyanskyy selyanyn, Kharkiv, Kyiv, 1-139. (In Ukrainian)

Novitsky, R. O., O. O. Hristov, D. L. Bondarev. 2008. Benthophiloides brauneri (Gobiidae, Perciformes) - a new species of the ichthyofauna of Dniprovske (Zaporizke) reservoir. Vestnik zoologii, 42 (6): 524.

Novitsky, R. O., S. V. Bilyk, A. O. Mishchenko. 2006. Persha znakhidka puholovky zirchastoyi Benthophilus stellatus stellatus na seredniy techiyi r. Samara v Dnipropetrovskiy obl. Vestnik zoologii, 40 (6): 528. (In Ukrainian)

Ostroumov, A. 1896. Opredelitel' ryb Chernogo i Azovskogo morey. Vestn. rybn. prom-ti, 7/9: 1-45. (In Russian)

Özen, Ö., H. Ayildiz, D. Tunca, M. Bilecenoğlu. 2009. First record of Gobius couchi Miller \& El-Tawil, 1974 from the Aegean Sea (Pisces: Gobiidae). Zool. Middle East, 47: 109-110.

Pankov, A. V. 2007. First Find of the Caucasian Goby, Knipowitschia caucasica (Pisces, Gobiidae), in the Freshwaters of Ukraine. Vestnik zoologii, 41 (1): 92. (In Ukrainian)

Pinchuk, V. I. 1968. O vidovom sostave bychkov roda Gobius razlichnykh rayonov Chernogo morya u beregov Sovetskogo Soyuza. Ekologicheskaya biogeografiya kontaktnykh zon morya. Naukova dumka, Kyiv, 126-134. (In Russian) 
Pinchuk, V. I. 1976. Sistematika bychkov rodov Gobius Linne (otechestvennye vidy), Neogobius Iljin, Mesogobius Bleeker. Vopr. ikhtiologii, 16, 4 (99): 600-609. (In Russian)

Pinchuk, V. I. 1977. Sistema bychkov rodov Gobius Linne (otechestvennyye vidy), Neogobius Iljin i Mesogobius Bleeker. Vopr. ikhtiologii, 17, 4 (105): 587-596. (In Russian)

Pinchuk, V. I. 1987. Taksonomicheskiye zametki o bychkovykh (Perciformes, Gobiidae) fauny Ukrainy. Vestnik zoologii, 5: 30-35. (In Russian)

Pinchuk, V. I., A. I. Smirnov, N. V. Koval, P. G. Shevchenko. 1985. O sovremennom rasprostranenii bychkovykh ryb (Gobiidae, Pisces) v basseyne Dnepra. Gidrobiologicheskiye issledovaniya presnykh vod. Sb. nauch. Tr., Naukova dumka, Kyiv, 121-130. (In Russian)

Pinchuk, V. I., E. D. Vasileva, P. J. Miller. 2004a. Benthophilus magistri Iljin, 1927. The Freshwater Fishes of Europe. Gobiidae 2. Wiebelsheim: AULA-Verlag, 8/2: 235-240.

Pinchuk, V. I., E. D. Vasileva, V. P. Vasilev, P. J. Miller. 2004b. Zosterisessor ophiocephalus (Pallas, 1814). The Freshwater Fishes of Europe. Gobiidae 2. AULA-Verlag, Wiebelsheim, 8/2: 5-32.

Pinchuk, V. I., M. Ya. Savchuk. 1982. O vidovom sostave bychkovykh ryb roda Pomatoschistus (Gobiidae) morey SSSR. Vopr. ikhtiologii, 22 (1): 9-14. (In Russian)

Pinchuk, V. I., P. J. Miller, E. D. Vasileva, V. P. Vasilev. 2003. Neogobius cephalargoides Pinchuk, 1976. The Freshwater Fishes of Europe. Gobiidae 1. AULA-Verlag, Wiebelsheim, 8/1: 181-192.

Pinchuk, V. I., P. J. Miller. 2004. Benthophiloides brauneri Beling and Iljin, 1927. The Freshwater Fishes of Europe. Gobiidae 2. AULA-Verlag, Wiebelsheim, 8/2: 153-159.

Pinchuk, V. I., P. V. Tkachenko. 1996. Pozvonochnyye zhivotnyye Chernomorskogo biosfernogo zapovednika (annotirovannyye spiski vidov). Ryby morskikh akvatoríy. Vestnik zoologii, 1. Otd. Vyp.: 5-14. (In Russian)

Prishchepa, R. E., A. R. Boltachev, E. P. Karpova. 2018. The diversity of gobies (Perciformes: Gobiidae) of the Karkinitsky gulf (the Black Sea coast of the Crimean peninsula). Tez. konf. "Biologicheskoye raznoobraziye: izucheniye, sokhraneniye, vosstanovleniye, ratsionalnoye ispolzovaniye", Kerch, 259-265. (In Russian)

Radu, G., E. Radu. 2008. Determinator al principalelor specii de pesti din Marea Neagra. Editura VIROM, Constanta, 1-558.

Rakauskas, V., T. Virbickas, K. Skrupskelis, V. Kesminas. 2018. Delayed expansion of Ponto-Caspian gobies (Pisces, Gobiidae, Benthophilinae) in the Nemunas River drainage basin, the northern branch of the central European invasion corridor. BioInvasions Records, 7 (2): 143-152.

Roche, K.F., M. Janač, P. Jurajda. 2013. A review of Gobiid expansion along the Danube-Rhine corridor geopolitical change as a driver for invasion. Knowledge and Management of Aquatic Ecosystems, 411, 01.

Romanescu, V. K. 2012. Goby fish (Perciformes: Gobiidae) in water bodies of the Republic of Moldova. Modern fisheries and environmental problems of the Azov-Black Sea region: Materials of the VII International Conference (Kerch, June 20-23, 2012), T. 2. YugNIRO, Kerch. 171-174. (In Russian)

Šanda, R., M. Kovačić. 2009. First record of Gobius couchi (Gobiidae) in the Ionian Sea. Cybium, 33 (3): 249-250.

Sari, H. M., S. L. Balik, M. Ustaolulu, A. Ulhan. 2006. Distribution and Ecology of Freshwater Ichthyofauna of the Biga Peninsula, North-western Anatolia, Turkey. Turk. J. Zool., 30: 35-45.

Scsepka, S., H. Ahnelt. 1999. Wiederbeschreibung von Gammogobius steinitzi Bath, 1971 sowie ein Erstnachweis von Corcyrogobius liechtensteini (Kolombatovic, 1891) fur Frankreich (Pisces, Gobiidae). Senckenbergiana biol, 79: 71-81.

Shaganov, V. V. 2009. Predvaritelnyy obzor ikhtiofauny chernomorskogo poberezhya yugo-vostochnogo Kryma. Sb. nauch. tr., posvyashch. 95-letiyu Karadag. nauch. stantsii i 30-letiyu Karadag. prirodn. zapovednika NAN Ukrainy, Sevastopol, 262-273. (In Russian)

Shaganov, V. V., A. I. Milovanov. 2005. Taksonomicheskiy sostav i osobennosti raspredeleniya bychkovykh ryb (Gobiidae, Perciformes) v pribrezhnoy zone Kerchenskogo proliva. Materialy Mezhdunar. konf., posvyashch. 140-letiyu osnovaniya Odes. nats. un-ta im. I. I. Mechnikova, 22-25 apr. 2005 g., Odesa, 332-333. (In Russian)

Shandikov, G. A., G. L. Goncharov. 2008. Redkiye vidy ryb basseyna Severskogo Dontsa Severo-vostochnoy Ukrainy. Vestnik Kharkovskogo natsionalnogo universiteta (Seriya: biologiya), 8 (828): 65-90. (In Russian)

Shandikov, G. A., D. V. Kryvokhyzha, I. V. Slipko. 2009. A First Record of the Caucasian Dwarf Goby Knipowitschia caucasica (Teleostei, Perciformes, Gobiidae), in the Siverskiy Donets River Drainage, Ukraine. Vestnik zoologii, 43 (4): 368.

Shekk, P. V. 2004. Ikhtiofauna Tiligulskogo limana. Prichornomor. ekol. byul., 2 (12): 101-111. (In Russian)

Skóra, K. E., J. Rzeznik. 2001. Observations on diet composition of the round goby, Neogobius melanostomus Pallas, 1811 (Gobiidae, Pisces) in the Gulf of Gdansk (Baltic Sea). J. Great Lakes Res., 27 (3): 290-299.

Slynko, Yu. V., E. A. Borovikova, V. V. Zamorov et al. 2012. The taxonomical status and distribution of species genera Proterorhinus into the Ponto-Caspian basin. Mater. V Mizhnar. ichtiol. nauk.-prakt. konf. "Suchasni problemy teoretichnoi ta praktichnoi ikhtiologii”.13-16 veresnya 2012, Chernivtsi, 212-216. (In Russian)

Smirnov, A. I. 1986. Okuneobraznye (bychkovidnye), skorpenoobraznye, kambaloobraznye, prisoskoperoobraznye, udilshchikoobraznye. Nauk. dumka, Kyiv, 1-320. (Series: Fauna Ukrainy; Vol. 8: Ryby, Issue 5). (In Russian)

Smirnov, A. I. 2006. Recent Ichthiofauna Status of the Molochny Firth of the Sea of Azov. Zbirn. pratz Zool. Muzeyu, 38: 23-33. (In Ukrainian)

Smirnov, A. I., V. A. Tkachenko. 2007. Ichthiodiversity Character as a Biotic Marker of Freshening of the Sasyk (Kunduk) Firth. Zbirn. pratz Zool. Muzeyu, 39: 41-56. (In Ukrainian) 
Snigirov, S. M. 2014. Biodiversity of ichthyofauna in Dnister Delta. Romanian J. of Geography, 58 (2): 189-200.

Snigirov, S. M., V. Z. Pitsyk ta in. 2018. "Chervonoknyzhni" vydy ryb pryberezhnykh vod ostrovu Zmiyinyy. Materialy do 4-ho vydannya Chervonoyi knyhy Ukrayiny. Tvarynnyy svit. Seriya: "Conservation Biology in Ukraine". 7 (2), Kyiv: 273-274. (In Ukrainian)

Snigiryov, S. M. 2008. Coastal zone ichthyofauna of the iseland Zmeiny. Visn. Odes. Nats. Un-tu, (Biology), 13 (4): 115-124. (In Russian)

Sorokin, P. A., D. A. Medvedev, V. P. Vasilev, E. D. Vasileva. 2011. Further studies of mitochondrial genome variability in Ponto-Caspian Proterorhinus species (Actinopterygii: Perciformes: Gobiidae) and their taxonomic implications. Acta ichthyol. et piscat., 41 (2): 95-104.

Stefanni, S., C. Mazzoldi. 1999. The presence of Couch's goby in the Mediterranean Sea. J. Fish Biol., 54 (5): $1128-1131$.

Stepanok, M. A., V. V. Hubanov. 2018. Znakhidky predstavnykiv fauny, zanesenykh do Chervonoyi knyhy Ukrayiny v ponyzzi Dnistra Materialy do 4 Vydannya Chervonoyi Knyhy Ukrayiny. Tvarynnyy svit. Kyiv, 295-296. (Series: "Conservation Biology in Ukraine". 7 (2)). (In Ukrainian)

Stepien, C. A., M. A. Tumeo. 2006. Invasion genetics of Ponto-Caspian gobies in the Great Lakes: a "cryptic" species, absence of founder effects, and comparative risk analysis. Biol. Invasions, 8: 61-78.

Strautman, I. F., V. I. Pinchuk. 1972. The discovery of the caspian goby Caspiosoma caspium (Kessler) in the Dniester estuary. Vestnik zoologii, 2: 81-83. (In Russian)

Sushkin, P. P., D. E. Beling. 1923. Opredelitel ryb presnovodnykh i morskikh Yevropeyskoy Rossii. Petrograd, 1-155. (In Russian)

Svetovidov, A. N. 1964. Fish of the Black Sea. Nauka, Moscow, Leningrad, 1-550. (In Russian)

Szalóky, Z., V. Bammer, Á. I. György, L. Pehlivanov, M. Schabuss et al. 2015. Offshore distribution of invasive gobies (Pisces: Gobiidae) along the longitudinal profile of the Danube River. Fundamental and Applied Limnology. Archiv Für Hydrobiologie, 187: 127-133.

Tkachenko, P. V. 2018. Vidomosti pro znakhidky vydiv ryb, zanesenykh do Chervonoyi knyhy Ukrayiny v rayoni Chornomorskoho biosfernoho zapovidnyka NAN Ukrainy (Tendrivska, Yahorlytska zatoky ta prylehla do nykh akvatoriya Chornoho morya) u 2009-2017 rr. Materialy do 4-ho vydannya Chervonoyi knyhy Ukrayiny. Tvarynnyy svit, Seriya: "Conservation Biology in Ukraine”. 7 (2), Kyiv, 329-331. (In Ukrainian)

Tret'yakov, D. K. 1947. Vyznachnyk kruhlorotykh i ryb URSR. K., Vyd-vo AN URSR, 1-112. (In Ukrainian)

Troitskiy, S. K., E. P. Tsunikova. 1988. Ryby basseynov Nizhnego Dona i Kubani. Rostov n/D., Rostovskoye. knizhnoye. izd-vo, 1-112. (In Russian)

Turan, D., S. Berber, E. T. Topkara, B. A. Verep. 2005. First Record Knipowitschia longicaudata (Kessler, 1877) for the Fish Fauna of Lake Manyas. Turk. J. Zool., 29: 171-176.

Van Kessel, N., M. Dorenbosch, F. Spikman. 2009. First record of Pontian monkey goby, Neogobius fluviatilis (Pallas, 1814), in the Dutch Rhine. Aquat. Invasions. 4 (2): 421-424.

Vasileva, E. D. 2007. Fish of the Black Sea. Key to Marine, Brackish-water, Euryhaline, and Anadromous Species with Color Illustrations Collected by S. V. Bogorodsky. VNIRO Publishing, Moskva, 1-238. (In Russian)

Vasileva, E. D., S. V. Bogorodskii. 2004. Two New Species of Gobies (Gobiidae) in the Ichthyofauna of the Black Sea. Journal of Ichthyology, 44 (8): 555-562.

Vassilev, M. V., L. Z. Pehlivanov. 2005. Checklist of Bulgarian Freshwater Fishes. Acta zool. Bulg., 57 (2): 161-190.

Vassilev, M., A. Apostolou, B. Velkov, D. Dobrev, V. Zarev. 2012. Atlas of the gobies Gobiidae) in Bulgaria. Institute of Biodiversity and Ecosystem Research, Bulgarian Academy of Sciences, 1-112.

Vinogradov, A. K, S. A. Khutornoy. 2013. Ikhtiofanua Odesskogo regiona severo-zapadnoy chasti Chernogo morya (biologicheskiye, ekologicheskiye, ekologo-morfologicheskiye osobennosti). Astroprint, Odessa, 1-224. (In Russian)

Vinogradov, K. A. 1949. Spisokryb Chernogo morya, vstrechayushchikhsya v rayone Karadagskoybiologicheskoy stantsii, s zamechaniyami ob ikh biologii i ekologii. Trudy Karadag. biol. stantsii, 7: 76-106. (In Russian)

Vinogradov, K. A., O. I. Tikhonov, L. I. Starushenko. 1967. Biologiya severo-zapadnoy chasti Chernogo morya. Ikhtiofauna. Kiev, 202-232. (In Russian)

Vladykov, V. 1926. Ryby Podkarpatskoy Rusi i ikh glavneyshiye sposoby lovli. Uzhgorod, 1-151. (In Russian)

Volovik, S. P., A. S. Chikhachev. 1998. Antropogennyye preobrazovaniya ikhtiofauny Azovskogo baseyna. Osnovnyye problemy rybnogo khozyaystva i okhrany rybokhozyaystvennykh vodoyemov Azovo-Chernomorskogo basseyna. Sb. nauch. tr. Azov. NII ryb. khoz-va (1996-1997). Rostov n/D., 7-23. (In Russian)

Vynogradov, K. O. 1947. Spysok ryb Chornoho morya, shcho zustrichayutsya v rayoni Karadahskoyi biolohichnoyi stantsiyi. Dop. AN URSR. Viddil biol. nauk, 5: 57-61. (In Ukrainian)

Vynogradov, K. O. 1960. Ikhtiofauna pivnichno-zakhidnoyi chastyny Chornoho morya. Vyd-vo Akademiyi nauk URSR, Kyiv, 1-116. (In Ukrainian)

Wirtz, P., R. Herrera. 1995. The lobster Enoplometopus antillensis (Decapoda: Enoplonetopidae), and the goby Gobius xanthocephalus (Pisces: Gobiidae) - new records for the marine fauna of the Canary islands. Arcquipelago Life and Marine Science, A 13: 115-118.

Zaitsev, Yu. 1998. The Most Blue in the World. New York, United Nations Publishing, 1-142. (In Russian)

Zambriborshch, F. S., D. Framudu. 1990. Sostav, otnositelnaya chislennost i raspredeleniye molodi ryb v Dnestrovskom limane. Gidrobiol. zhurn., 26 (1): 47-50. (In Russian) 
Zambriborshch, F. S., M. A. Vinnikova, V. V. Zamorov. 1995. Ryby Odesskogo zaliva v proshlom i nastoyashchem. Nauch. tr. Zool. muzeya Odes. un-ta im. I. I. Mechnikova, 2: 19-26. (In Russian)

Zelenin, A. M., M. Z. Vladimirov. 1975. Novye dannye o raspredelenii i biologii bychka Knipowitschia longicaudata (Kessler) v basseyne Dunaya. Izv. AN MSSR, 5: 44-46. (In Russian)

Zenkevich, L. A. 1963. Biologiya morey SSSR. Izd-vo AN SSSR, Moskva, 1-739. (In Russian)

Zogaris, S., A. Apostolou. 2011. First record of Pontian Monkey Goby, Neogobius fluviatilis (Pallas, 1814) in the Evros River (Greece): Is it an alien species? Mediterranean Marine Science, 12 (2): 454-461. 